\title{
Gross Anatomy of the Digestive Tract of the Hawaiian Monk Seal, Monachus schauinslandi ${ }^{1}$
}

\author{
Gwen D. Goodman-Lowe, ${ }^{2}$ Shannon Atkinson, ${ }^{3}$ and fames R. Carpenter 4
}

\begin{abstract}
The digestive tract of a female juvenile Hawaiian monk seal was dissected and described. Intestine lengths were measured for a total of 19 seals ranging in age from 1 day old to over $10 \mathrm{yr}$ old. Small intestine (SI) lengths were measured for 10 seals and ranged from 7.1 to $16.2 \mathrm{~m}$; mean SI to standard ventral length (SVL) ratio was $7.1 \pm 0.9 \mathrm{~m}$. Large intestine (LI) lengths were measured for 11 seals and ranged from 0.4 to $1.2 \mathrm{~m}$; mean LI:SVL was $0.5 \pm 0.1 \mathrm{~m}$. Total intestine (TI) lengths were measured for 18 seals and ranged from 7.5 to $18.4 \mathrm{~m}$; total intestine length to SL ratio was $7.9 \pm 1.3 \mathrm{~m}$. SI and LI lengths both exhibited a linear relationship relative to SVL, whereas stomach weight:SVL showed an exponential relationship. TI:SVL was significantly smaller than ratios determined for harbor, harp, and northern elephant seals, but was not significantly different from those of crabeater, leopard, and Ross seals. No correlation was seen between gut length and body length for seven species of seals, including the Hawaiian monk seal.
\end{abstract}

The Hawailan monk seal, Monachus schauinslandi, has a population currently estimated at 1300 individuals with a decline currently occurring at French Frigate Shoals (FFS) (National Marine Fisheries Service [NMFS], unpubl. data), where one of the largest subpopulations exists. The decline at FFS is likely due, in part, to the starvation of juvenile seals (Gilmartin 1993). Because the assimilation of ingested prey is affected by digestive tract morphology in species that have been studied (Lawson et al. 1997), it is essential to understand all aspects of the

${ }^{1}$ This project was made possible by the National Marine Fisheries Service, Honolulu, with funding from the Sea Grant College Program at the University of Hawai'i (Institutional Grant No. NA36RG0507, Publication UNHI-SEAGRANT-JC-98-44). Manuscript accepted 19 February 2001.

${ }^{2}$ Department of Biology, California State University, Long Beach, Long Beach, California 90840.

${ }^{3}$ Alaska SeaLife Center, University of Alaska, Seward, Alaska 99664.

${ }^{4}$ Department of Human Nutrition, Food, and Animal Sciences, University of Hawai'i at Mānoa, Honolulu, Hawai'i 96822.

Pacific Science (2001), vol. 55, no. 4:399-407 (C) 2001 by University of Hawai'i Press All rights reserved monk seal's digestive physiology, including gross anatomy of the digestive tract.

Data on intestinal lengths have been compiled for most species of pinnipeds (King 1969), including the rare Mediterranean monk seal, Monachus monachus (Schnapp et al. 1962). In addition, the gastrointestinal tract has been described for several species of pinnipeds (e.g., Weddell seal [Leptonychotes weddelli]: Eastman and Coalson [1974]; crabeater seal [Lobodon carinophagus], harbor seal [Phoca vitulina], and northern elephant seal [Mirounga angustirostris]: Bryden and Erikson [1976], Helm [1983]; harp seal [Phoca groenlandica]: Olsen et al. [1996]); however, the digestive tract of the Hawaiian monk seal has not been described previously. The purpose of this study was to describe the gross anatomy of the seal's digestive tract and also to determine whether differences exist in intestine length between the Hawaiian monk seal and other pinnipeds previously examined.

\section{MATERIALS AND METHODS}

Intestinal lengths were measured from 19 Hawaiian monk seals collected in the main Hawaiian islands and Northwestern Hawaiian Islands (NWHI) that died between 1996 and 1998. Ages of these seals were $1 \mathrm{~d}(n=1), 5 \mathrm{~d}$ 
$(n=1), 9 \mathrm{~d}(n=1),<1 \mathrm{yr}(n=9), \mathrm{J} 2(n=1)$, adult $(n=2),>10 \mathrm{yr}(n=1)$; J2 seals are approximately 2 yr old and adults are approximately $>5$ yr old. For seals less than 5-6 weeks old (age at weaning), the exact birth date was known. For weaned and juvenile seals, age was determined via plastic identification tags attached to the hind flippers. Age of adult seals was estimated from size, except in the case of the seal $>10 \mathrm{yr}$, where age was estimated by dentition condition. Seals had died from a variety of causes, including drowning by adult males, mobbing of the mother just before birth, perinatal death, shark injury, abscess from a conspecific injury, direct mobbing injury, and possibly old age (NMFS, unpubl. data). Death directly from starvation was not apparent for any of the seals examined.

For 8 of the 19 seals, the entire digestive tract from tongue to anus was collected and fixed in $10 \%$ formalin, and lengths and weights of the tongue, esophagus, stomach, small intestines (SI), and large intestines (LI) were recorded. Formalin-fixed organs exhibited a decrease in elasticity, but not overall

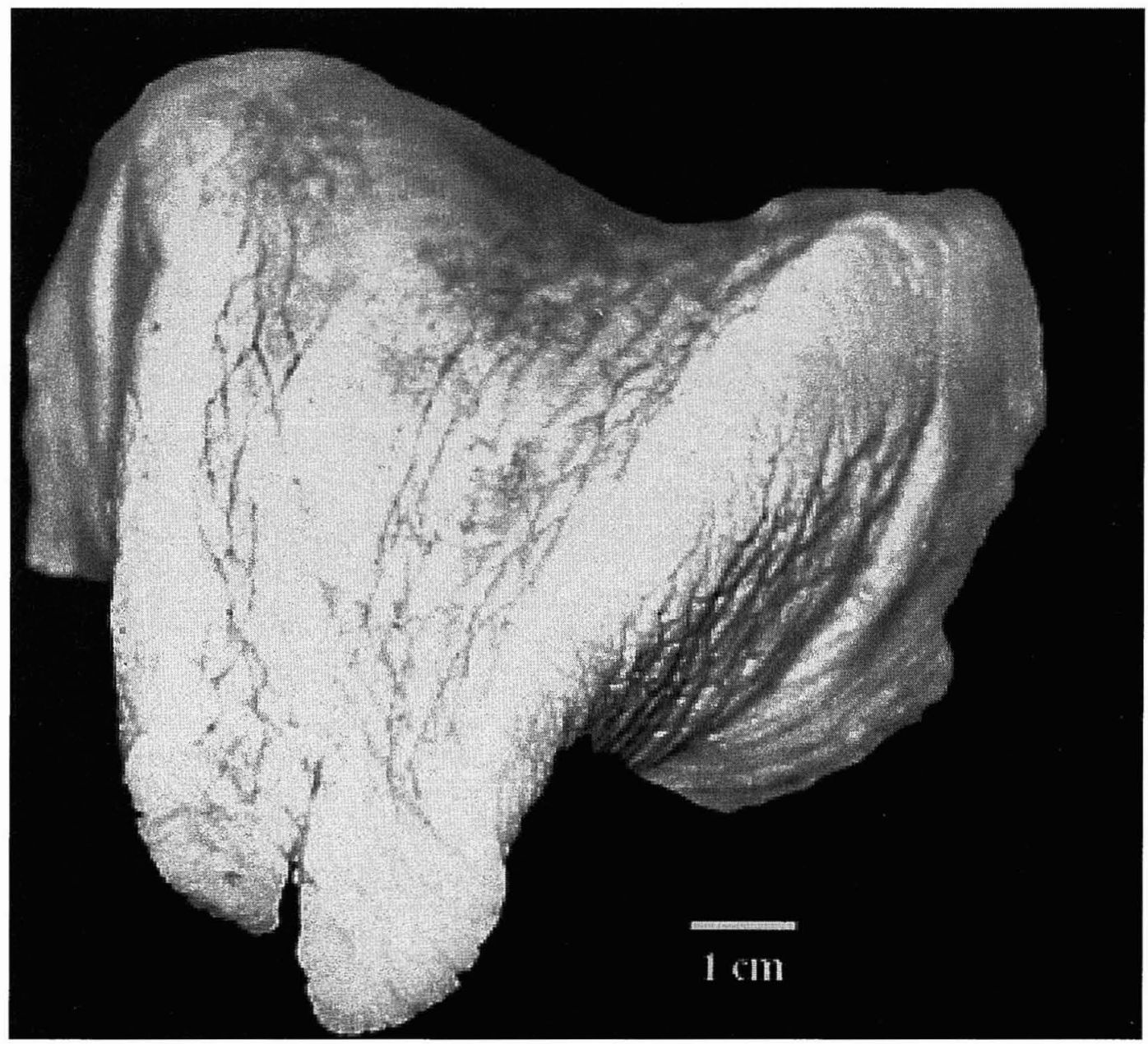

FIgURE 1. Tongue of Hawaiian monk seal showing bifurcation at tip. 


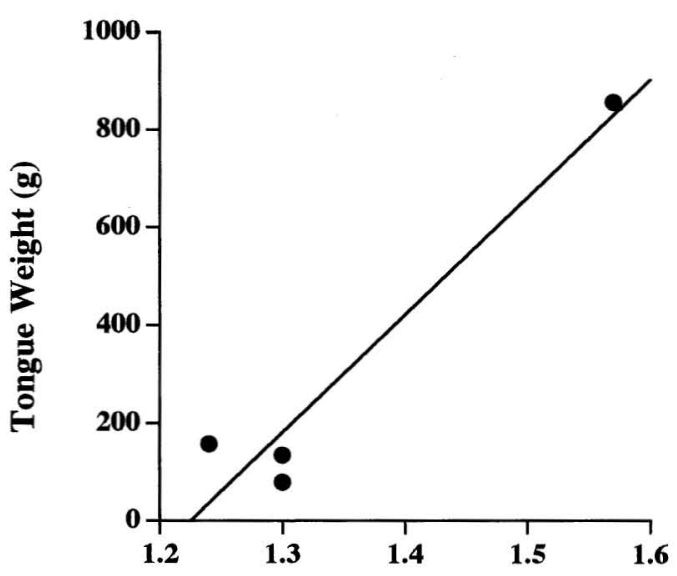

Body Length (m)

Figure 2. Body length (m) of Hawaiian monk seals versus tongue weight $(\mathrm{g})(n=4)$, where $y=2410.183 x-$ 2952.748 and $r^{2}=0.932$.

size $(t=-1.35, P=0.20)$. The remainder of the seals were measured during necropsies conducted in the field; hence, measurements were made on freshly dead, not preserved animals. Stomachs were emptied of their contents before measuring. Both the SI and LI were laid out in a straight line and measured to the nearest centimeter. SI were measured for 10 of the seals and large intestines measured for 11 of the seals. Eight of the seals had only total intestines (TI) recorded. Standard ventral length (SVL) was measured for all seals. Because the SI is the organ involved in absorbing nutrients during digestion and should therefore be correlated with time of digestion, only differences between the SI and TI length to SVL ratios among seal species were examined using a one-way analysis of variance and Student's $t$-test (SAS Institute 1985).

\section{RESULTS}

The morphology of the Hawaiian monk seal gastrointestinal tract was similar to that of many carnivores. The tongue, as in otariids and other phocids (Eastman and Coalson 1974) was bifurcated at the tip (Figure 1), with a mean underside cleft length of $1.3 \pm$ $0.4 \mathrm{~cm}(n=4)$. The tongue length was similar among the seals, but was highly variable in weight, with younger seals having smaller tongues (Figure 2, Table 1). The esophagus narrowed from cranial to caudal end (upper portion diameter, $3.81 \mathrm{~cm}$; lower portion diameter, $2.86 \mathrm{~cm})(n=1)$, with thicker walls nearer to the stomach. In addition, rather than being smooth and unfolded internally, the esophagus had several longitudinal parallel folds of various sizes. The esophagus was also similar in length among the seals examined, but did vary in weight (Table 1). Cause of death did not appear to affect either the

TABLE 1

Descriptive Measurements of Eight Formalin-Fixed Digestive Tracts from Hawaiian Monk Seal Newborns and Pups Ranging in Age from $1 \mathrm{~d}$ to Approximately 2 Yr Old

\begin{tabular}{lccc}
\hline \hline Organs & Length $(\mathrm{m})$ & Weight $(\mathrm{g})$ & Notes \\
\hline $\begin{array}{l}\text { Tongue } \\
(n=4)\end{array}$ & $0.13 \pm 0.04$ & $246.4 \pm 347.0$ & Bifurcated \\
$\begin{array}{l}\text { Esophagus } \\
(n=4)\end{array}$ & $0.38 \pm 0.05$ & $116.5 \pm 13.9$ & Walls thickened toward proximal end \\
$\begin{array}{l}\text { Stomach } \\
(n=8)\end{array}$ & $0.23 \pm 0.05$ & $308.0 \pm 292.9$ & Bent sharply backward \\
$\begin{array}{l}\text { Small intestine } \\
(n=8)\end{array}$ & $9.02 \pm 2.15$ & $1,004.3 \pm 614.2$ & Circumference variable \\
$\begin{array}{l}\text { Large intestine } \\
(n=8)\end{array}$ & $0.58 \pm 0.16$ & $191.6 \pm 154.5$ & Circumference variable \\
\hline
\end{tabular}




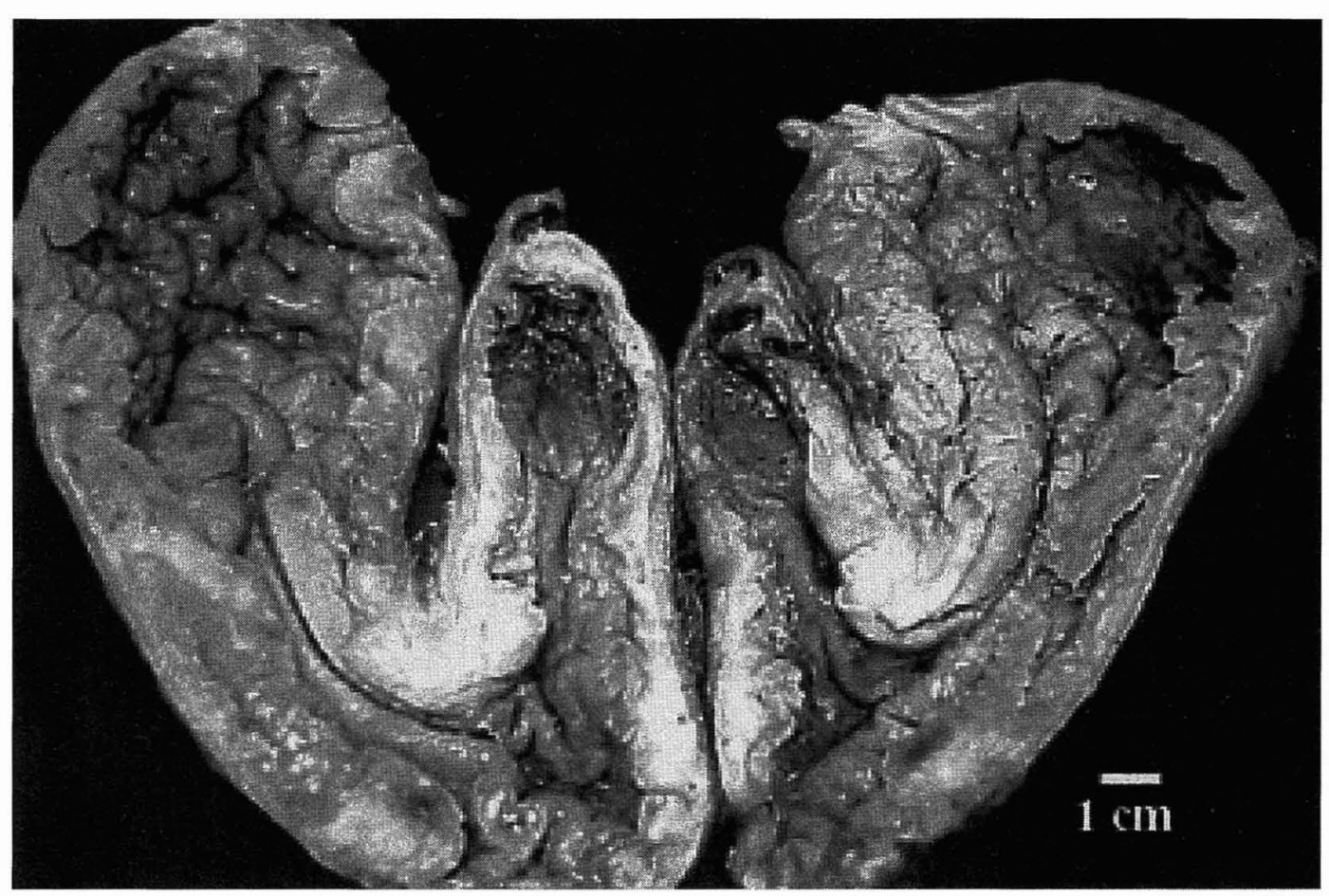

FIGURE 3. Internal view of stomach of Hawaiian monk seal.

appearance or the lengths and weights of the digestive tract components.

The tunica muscularis of the stomach was thick with a distinct pyloric section bent sharply backward $(n=17)$. In all stomachs examined, the mucosa of the fundus and body was arranged in sections of large and irregular gastric folds; the pyloric part had small parallel folds (Figure 3). The length of the stomach was similar among the monk seals examined, but the weight was variable. Stomach weight-to-SVL ratios for monk seals $<1$ yr (mean: $127.4 \pm 26.5, n=6$ ) versus monk seals $>2$ yr (mean: $504.2 \pm 59.8, n=2$ ) were significantly different $(t=-8.69, \mathrm{df}=$ $7, P=0.036)$, with older/larger seals having more muscular, heavier stomachs (Figure 4). Stomach weight to SVL ratios for all juvenile or younger monk seals were significantly smaller than those found by Olsen et al.

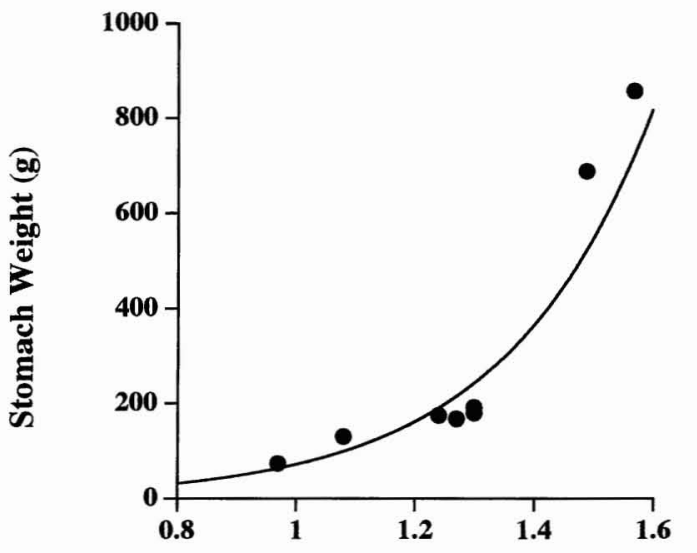

\section{Body Length (m)}

Figure 4. Body length (m) of Hawaiian monk seal versus stomach weight $(\mathrm{g})(n=8)$, where $y=1.248 x-10^{1.760 x}$ and $r^{2}=0.914$. 
TABLE 2

Comparative Small Intestine (SI), Large Intestine (LI), and Total Intestine (TL) to Standard Ventral Length (SVL) Ratios in Phocid Seals

\begin{tabular}{|c|c|c|c|c|c|c|c|c|c|}
\hline Species & Age; Sex ${ }^{a}$ & SVL (m) & $\begin{array}{l}\text { SI length } \\
(\mathrm{m})\end{array}$ & $\begin{array}{l}\text { LI length } \\
\text { (m) }\end{array}$ & $\begin{array}{l}\text { TI length } \\
(\mathrm{m})\end{array}$ & SI:SVL & LI:SVL & TI:SVL & Reference \\
\hline \multirow[t]{2}{*}{ Harp seal } & $\begin{array}{c}2-29 \mathrm{yr} ; M / \mathrm{F} \\
(n=12)\end{array}$ & $1.6 \pm 0.1$ & $22.8 \pm 1.6$ & $0.6 \pm 0.1$ & $23.4 \pm 1.6$ & $9.9 \pm 1.3$ & $0.4 \pm 0.1$ & $14.7 \pm 1.5$ & Olsen et al. (1996) \\
\hline & $\begin{array}{l}\text { Adult; M/F } \\
\quad(n=7)\end{array}$ & & & & & $12.3 \pm 1.2$ & & & $\begin{array}{l}\text { Martensson et al. } \\
\quad(1998)\end{array}$ \\
\hline Harbor seal & $\begin{array}{l}\text { Weaned pups- } \\
\text { yearlings; } M / \mathrm{F} \\
(n=19)\end{array}$ & $0.8 \pm 0.2$ & $13.2 \pm 3.1$ & $0.5 \pm 0.2$ & $13.7 \pm 3.4$ & $15.9 \pm 2.7$ & $0.6 \pm 0.1$ & $16.2 \pm 2.8$ & Helm (1983) \\
\hline $\begin{array}{l}\text { Mediterranean } \\
\text { monk seal }\end{array}$ & $\begin{array}{l}\text { Juvenile; } \mathbf{F} \\
\qquad(n=1)\end{array}$ & 1.5 & 8.7 & 0.4 & 9.1 & 5.7 & 0.3 & 5.9 & $\begin{array}{l}\text { Schnapp et al. } \\
(1962)\end{array}$ \\
\hline $\begin{array}{l}\text { Hawaiian } \\
\text { monk seal }\end{array}$ & $\begin{array}{l}1 \mathrm{~d} \text {-adult; } \mathrm{M} / \mathrm{F} \\
(n=19)\end{array}$ & $1.4 \pm 0.4$ & $10.3 \pm 3.4$ & $0.7 \pm 0.3$ & $11.3 \pm 3.9$ & $7.1 \pm 0.9$ & $0.5 \pm 0.1$ & $7.9 \pm 1.3$ & This study \\
\hline \multirow[t]{2}{*}{ Crabeater seal } & $\begin{array}{c}\text { 4-9 yr; M/F } \\
(n=3)\end{array}$ & $2.2 \pm 0.3$ & $25.3 \pm 4.7$ & $0.9 \pm 0.3$ & $26.3 \pm 5.0$ & $11.3 \pm 2.2$ & $0.4 \pm 0.1$ & $11.7 \pm 2.3$ & $\begin{array}{l}\text { Bryden and Erikson } \\
\text { (1976) }\end{array}$ \\
\hline & $\begin{array}{l}\text { Adult; M/F } \\
\quad(n=2)\end{array}$ & & & & & 10.0 & & & $\begin{array}{l}\text { Martensson et al. } \\
\text { (1998) }\end{array}$ \\
\hline \multirow[t]{2}{*}{ Leopard seal } & $\begin{array}{l}\text { Adult; } M / F \\
\quad(n=2)\end{array}$ & $2.8 \pm 0.3$ & $21.9 \pm 0.4$ & $1.7 \pm 0.7$ & $23.6 \pm 0.3$ & $7.8 \pm 1.0$ & $0.6 \pm 0.2$ & $8.4 \pm 0.9$ & King (1983) \\
\hline & $\begin{array}{l}\text { Adult; } M / F \\
\quad(n=1)\end{array}$ & & & & & 10.2 & & & $\begin{array}{l}\text { Martensson et al. } \\
\text { (1998) }\end{array}$ \\
\hline \multirow[t]{2}{*}{ Ross seal } & $\begin{array}{l}\text { 4-yr adult; M/F } \\
\quad(n=2)\end{array}$ & $2.2 \pm 0.2$ & $7.9 \pm 4.8$ & $0.8 \pm 0.3$ & $8.7 \pm 5.1$ & $3.6 \pm 1.9$ & $0.4 \pm 0.1$ & $4.0 \pm 1.6$ & $\begin{array}{l}\text { King (1969), Bryden } \\
\text { and Erikson } \\
\text { (1976) }\end{array}$ \\
\hline & $\begin{array}{l}\text { Adult; } M / F \\
\quad(n=1)\end{array}$ & & & & & 4.8 & & & $\begin{array}{l}\text { Martensson et al. } \\
\text { (1998) }\end{array}$ \\
\hline $\begin{array}{l}\text { Southern } \\
\text { elephant } \\
\text { seal }\end{array}$ & $\begin{array}{l}\text { Adult; } M / F \\
\quad(n=4)\end{array}$ & $3.9 \pm 1.0$ & $121.0 \pm 57.7$ & - & - & $29.9 \pm 8.1$ & - & - & Laws (1953) \\
\hline $\begin{array}{l}\text { Northern } \\
\text { elephant } \\
\text { seal }\end{array}$ & $\begin{array}{l}\text { Weaned pups- } \\
\text { yearlings; } \mathrm{M} / \mathrm{F} \\
(n=14)\end{array}$ & $1.5 \pm 0.2$ & $38.2 \pm 6.3$ & $0.5 \pm 0.1$ & $38.7 \pm 6.3$ & $25.5 \pm 3.7$ & $0.3 \pm 0.1$ & $25.8 \pm 3.7$ & Helm (1983) \\
\hline Weddell seal & $\begin{array}{l}\text { Adult; } M / F \\
\quad(n=1)\end{array}$ & & & & & 10.2 & & & $\begin{array}{l}\text { Martensson et al. } \\
\text { (1998) }\end{array}$ \\
\hline Ringed seal & $\begin{array}{c}\text { Adult; } M / F \\
(n=3)\end{array}$ & & & & & $13.0 \pm 0.5$ & & & $\begin{array}{l}\text { Martensson et al. } \\
\text { (1998) }\end{array}$ \\
\hline Hooded seal & $\begin{array}{l}\text { Adult; } M / F \\
\quad(n=10)\end{array}$ & & & & & $13.0 \pm 1.4$ & & & $\begin{array}{l}\text { Martensson et al. } \\
\text { (1998) }\end{array}$ \\
\hline
\end{tabular}

${ }^{a} \mathrm{M}$, male; F, female. 


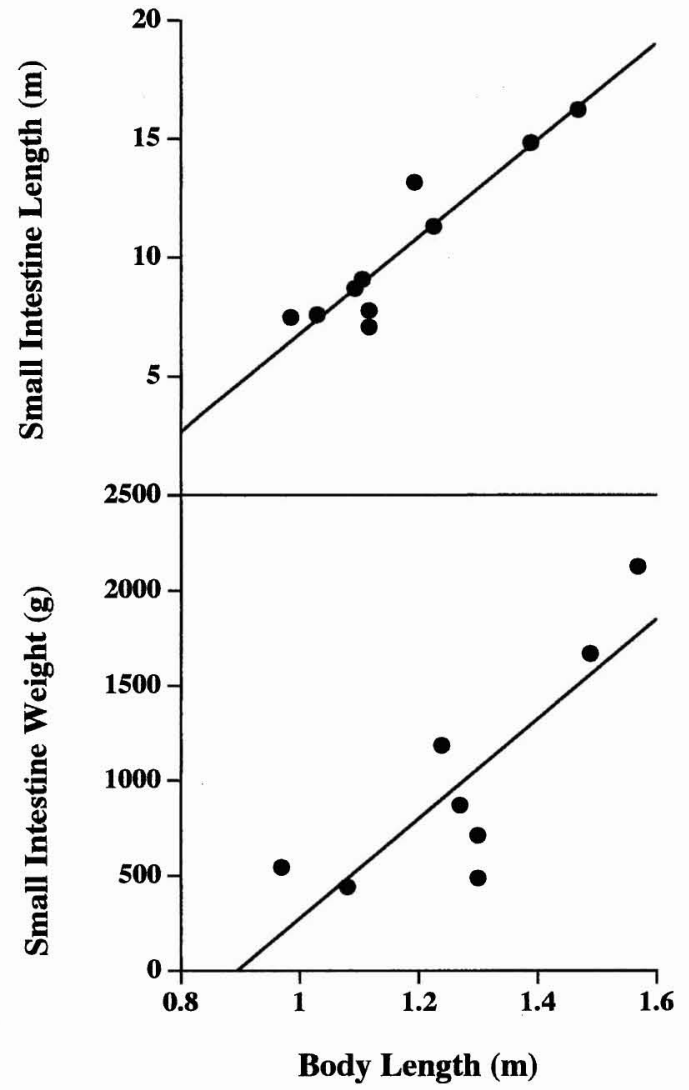

Figure 5. Body length (m) of Hawaiian monk seal versus small intestine length $(\mathrm{m})(n=10)$, where $y=8.162 x-$ 1.411 and $r^{2}=0.867$, and versus small intestine weight (g) $(n=8)$, where $y=2621.637 x-2344.854$ and $r^{2}=0.694$.

(1996) for adult harp seals $(t=-2.64, \mathrm{df}=9$, $P=0.027)$. Remnants of prey were found in only two stomachs, both of which were from juvenile seals.

The SI/LI junction was apparent as a narrowing of the SI with a slight diverticulum just before the start of the LI. The SI contained no identifiable dietary contents and its weight was variable. The SI ranged from 7.1 to $16.2 \mathrm{~m}$ in length (mean: $9.02 \pm 2.15 \mathrm{~m}$ [Table 1]). For all of the seals for which SI length was measured, the SI:SVL was $7.1: 1 \pm 0.9(n=10$ [Table 2]). This did not differ among the age groups of Hawaiian monk seals $(F=2.03, \mathrm{df}=9, \quad P=0.201)$ and, thus, age groups were pooled for analysis by species. SI:SVL ratios were significantly smaller than those found for the harp and southern elephant seals (Mirounga leonina) $(F=73.64, \mathrm{df}=25, P=0.000)$, but not different from those of the crabeater, leopard (Hydrurga leptonyx), or Ross seals (Ommatophoca rossi). Both SI length and weight increased with increasing age/size of the seal (Figure 5).

The LI ranged from 0.41 to $0.70 \mathrm{~m}$ (mean: $0.58 \pm 0.16 \mathrm{~m}$ ) long and varied in both weight and circumference (Table 1). The LI:SVL ratio was $0.5: 1 \pm 0.1(n=11$ [Table 2]). This did not differ among the age groups of Hawaiian monk seals $(F=2.03$, $\mathrm{df}=9, P=0.201)$ and, thus, age groups were pooled for analysis by species. LI:SVL ratios were significantly larger than that found for the harp seal $(t=3.08, \mathrm{df}=17, P=0.007)$, but not different from those of the crabeater, leopard, or Ross seals. Although LI length increased with increasing age/size of the seal, little correlation was seen between LI weight and age/size of seals $(F=1.34, \mathrm{df}=6, P=$ 0.299) (Figure 6).

The TI:SVL ratio was $7.9: 1 \pm 1.3(n=$ 18 [Table 2]). This did not differ among the age groups of Hawaiian monk seals $(F=1.88, \mathrm{df}=17, P=0.187)$ and, thus, age groups were pooled for analysis by species. Hawaiian monk seal TI:SVL ratios were significantly lower than harp seal, harbor seal, and northern elephant seal ratios $(F=$ $119.95, \mathrm{df}=60, P=0.000$ ), but not different from those of crabeater, leopard, or Ross seals $(F=5.0, \mathrm{df}=24, P=0.111)$. In addition, no correlation was seen between TI and SVL among these seven species of seals $(F=0.2$, $\mathrm{df}=6, P=0.677$ ) (Figure 7).

\section{DISCUSSION}

The gastrointestinal tract of the Hawaiian monk seals examined was found to be similar to that of many pinnipeds in that it had a bifurcated tongue, esophagus, simple stomach sharply bent cardioesophageally, SI, and a relatively short LI (Eastman and Coalson 


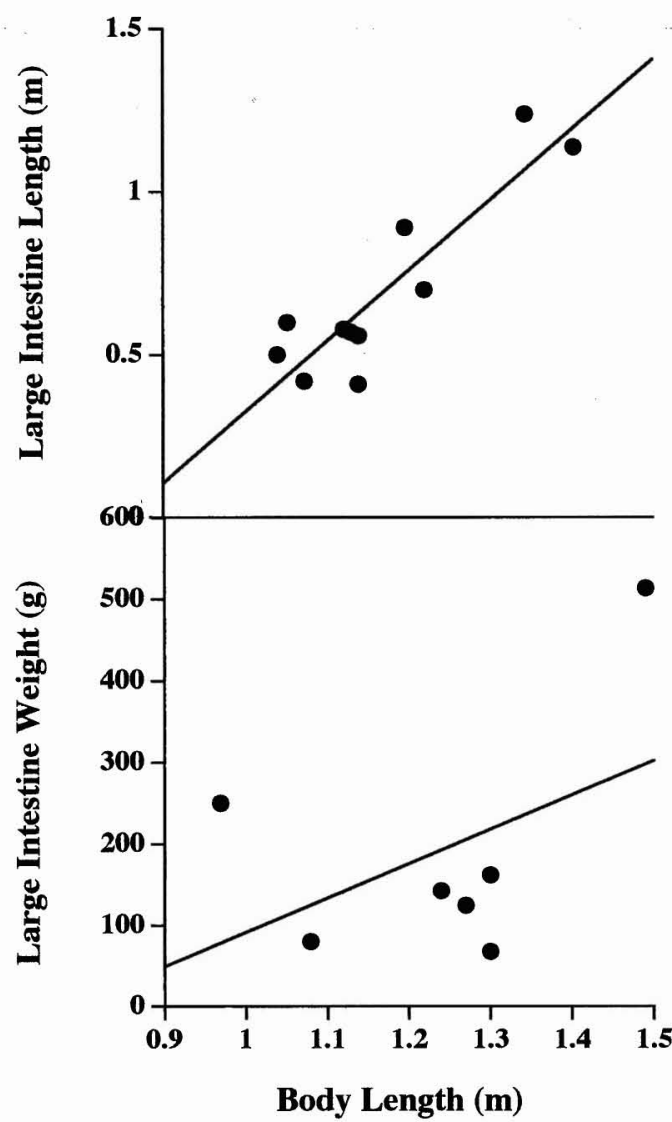

FIGURE 6. Body length (m) of Hawaiian monk seal versus large intestine length $(\mathrm{m})(n=11)$, where $y=0.625 x-$ 0.220 and $r^{2}=0.804$, and versus large intestine weight $(\mathrm{g})$ $(n=7)$, where $y=423.831 x-332.091$ and $r^{2}=0.212$.

1974, Olsen et al. 1996). Although 8 of the 19 digestive tracts were fixed in buffered formalin, thus possibly affecting elasticity and length of the structures examined, no significant difference was seen between formalinfixed and nonfixed TI:SVL ratios. In addition, the SI/LI junction was not indicated by a distinct caecum as seen in other seals (Olsen et al. 1996).

Ratios of the SI, LI, and TI to SVL did not differ among very young seals, juveniles, and adults. However, the circumference, musculature, and weight all increased with age. This may be due to the fact that young seals digest milk only, which does not require large amounts of musculature for peristalsis, whereas older stomachs become more muscular later to process fish, cephalopods, and crustaceans. Similarly, harp seal stomach weights standardized to SVL measured from seals that were $\geq 9$ yr old $(n=11)$ (Olsen et al. 1996) were greater than monk seal stomach weights measured from seals $\leq 1 \mathrm{yr}$ old $(n=6)$.

Data on the individual SI lengths of harbor and northern elephant seals are not available. However, based on the averages of these lengths (Table 2), one can predict that the Hawaiian monk seal SI:SVL ratio would be lower than in those species. Likewise, TI lengths of southern elephant seals are probably larger than those of Hawaiian monk seals because the SI:SVL ratio is greater. Therefore, the SI and TI:SVL ratios for Hawaiian monk seals are probably smaller than those of harp, harbor, and northern and southern elephant seals.

King (1983) suggested that the length of the digestive tract is not directly related to diet. For instance, seals with similar prey types, such as the southern elephant seal and Ross seal, which both feed predominantly on squid, have quite different SI:SVL ratios $(29.9 \pm 8.1 \mathrm{~m}$ versus $3.6 \pm 1.9 \mathrm{~m}$, respectively) (King 1983). Martensson et al. (1998) concluded that gut length was more closely correlated with body length than with maximum dive duration or capacity. However, comparing the TI with SVL in seven species of seals, including the Hawaiian monk seal, resulted in no correlation between gut length and body length.

\section{ACKNOWLEDGMENTS}

We thank B. LeaMaster, J. Choulijan, B. Becker, and E. Kashinsky for helping with the measurements and dissections, and W. Gilmartin, D. Greenfield, R. Kinzie, and E. Reese for reviewing the manuscript. The views expressed herein are those of the authors and do not reflect the views of NOAA or any of its subagencies. 


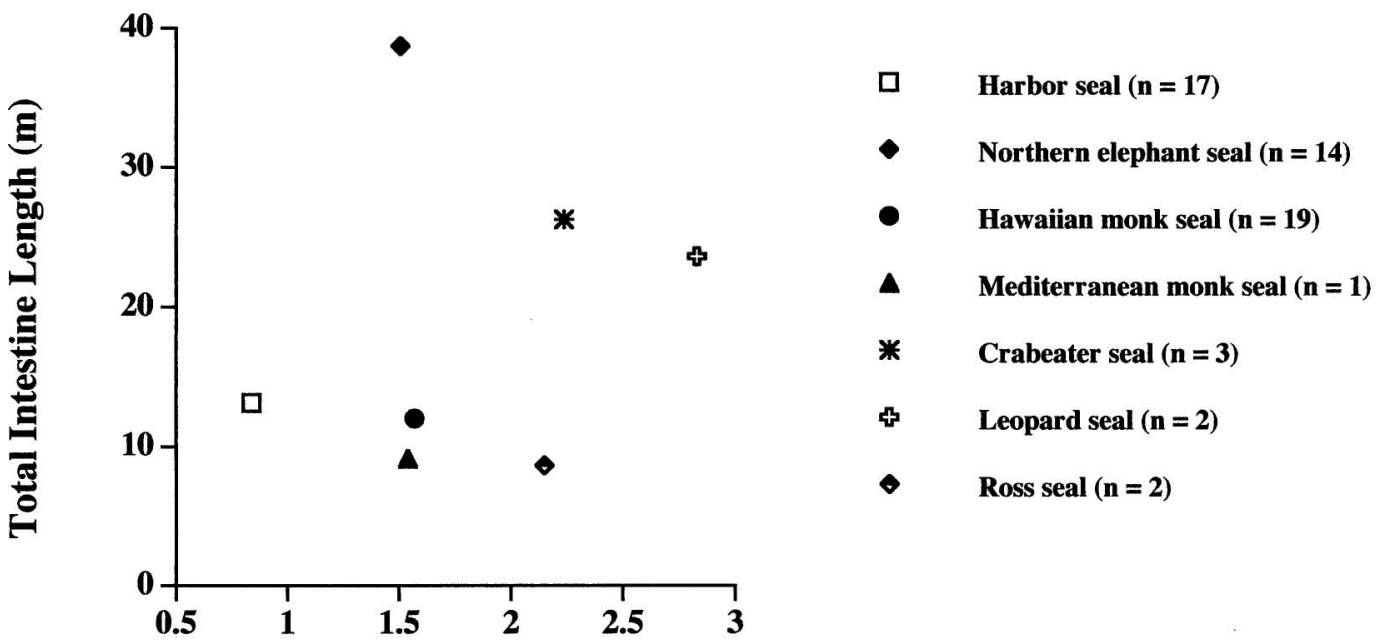

\section{Standard Ventral Length (m)}

Figure 7. Body length $(m)$ of total intestine length versus standard ventral length $(m)(n=7)$ in seven species of seals, where $y=0.01 x+1.6186$ and $r^{2}=0.038$.

\section{Literature Cited}

Bryden, M. M., and A. W. Erikson. 1976. Body size and composition of crabeater seals (Lobodon carcinophagus) with observations on tissue and organ size in Ross seals (Ommatophoca rossi). J. Zool. (Lond.) 179:235-247.

Eastman, J. T., and R. E. Coalson. 1974. The digestive system of the Weddell seal, Leptonychotes weddelli-a review. Pages 253-319 in R. J. Harrison, ed. Functional anatomy of marine mammals. Vol. 2. Academic Press, London.

Gilmartin, W. G. 1993. Research and management plan for the Hawaiian Monk Seal at French Frigate Shoals, 1993-1996. Southwest Fisheries Service Center, National Marine Fisheries Service, NOAA, Honolulu. SWFC Administrative Report H-93-08, June (1993).

Helm, R. C. 1983. Intestinal length of three California pinniped species. J. Zool. (Lond.) 199:297-304.
King, J. E. 1969. Some aspects of the anatomy of the Ross seal, Ommatophoca rossi (Pinnipedia: Phocidae). Br. Antarct. Surv. Sci. Rep. 63.

1983. Seals of the world, 2 nd ed. Cornell University Press, Ithaca, New York.

Laws, R. M. 1953. The elephant seal (Mirounga leonina Linn.). I. Growth and age. Falkl. Isl. Depend. Surv. Sci. Rep. 8:1-62.

Lawson, J. W., E. H. Miller, and E. Noseworthy. 1997. Variation in assimilation efficiency and digestive efficiency of captive harp seals (Phoca groenlandica) on different diets. Can. J. Zool. 75:1285-1291.

Martensson, P., E. S. Nordoy, E. B. Messelt, and A. S. Blix. 1998. Gut length, food transit time and diving habit in phocid seals. Polar Biol. 20:213-217.

Olsen, M. A., K. T. Nilssen, and S. D. Mathiesen. 1996. Gross anatomy of the gastrointestinal system of harp seals (Pboca groenlandica). J. Zool. (Lond.) 238:581589. 
SAS Institute. 1985. SAS users guide: Statistics. Version 5. SAS Institute, Inc., Cary, North Carolina.

Schnapp, B., S. Hellwing, and G. Ghizelea.
1962. Contributions to the knowledge of the Black Sea seal (Monachus monachus). Trav. Mus. Hist. Nat. 'Grigore Antipa' 3:382-400. 